\title{
HUBUNGAN KECUKUPAN KONSUMSI FE, POLA MAKAN DAN UKURAN LILA DENGAN ANEMIA IBU HAMIL DI PUSKESMAS SIMPANG KAWAT KOTA JAMBI
}

\author{
Ruwayda*, Nurmisih \\ Jurusan Kebidanan Poltekkes Kemenkes Jambi, Indonesia \\ * Korespondensi penulis: ida_dodyrz@yahoo.co.id
}

\begin{abstract}
ABSTRAK
Latar Belakang: Angka kejadian anemia di Indonesia menunjukkan nilai yang cukup tinggi. Anemia merupakan penurunan kuantitas atau kualitas sel-sel darah merah dalam sirkulasi. Anemia yang sering terjadi pada kehamilan adalah anemia defisiensi zat Fe. Status gizi yang kurang dapat menjadi predisposisi anemia ibu hamil di Indonesia yang salah satu indikatornya dapat diketahui dengan mengukur Lingkar Lengan Atas (LILA). Penelitan ini bertujuan untuk mengetahui hubungan kecukupan konsumsi Fe, pola makan dan ukuran LILA dengan anemia ibu hamil di Puskesmas Simpang Kawat Kota Jambi

Metode Penelitian ini menggunakan rancangan cross sectional. Populasi sebanyak 526 orang dengan jumlah sampel 97 ibu hamil yang berkunjung dan bertempat tinggal di wilayah kerja Puskesmas Simpang Kawat. Teknik pengambilan sampel secara quota sampling. Responden merupakan wanita hamil yang mendatangi poli Kesehatan Ibu Anak Puskesmas Simpang Kawat.

Hasil: Sebanyak $72(74,2 \%)$ responden mengalami anemia. Ada hubungan kecukupan konsumsi tablet Fe dengan anemia ibu hamil $(p=0,006)$ dan tidak terdapat hubungan pola makan $(p=0,279)$ dan ukuran LILA dengan anemia ibu hamil $(p=0,178)$.

Kesimpulan: Ada hubungan kecukupan konsumsi tablet Fe dengan anemia ibu hamil dan tidak terdapat hubungan pola makan dan ukuran LILA dengan anemia ibu hamil
\end{abstract}

Kata Kunci: anemia dalam kehamilan; tablet Fe; LILA.

THE RELATIONSHIP BETWEEN Fe ADEQUACY, DIETARY PATTERN AND MIDDLE UPPER ARM CIRCUMFERENCE (MUAC) LEVEL WITH ANEMIA IN PREGNANCY AT PUSKESMAS SIMPANG KAWAT JAMBI CITY

\section{ABSTRACT}

Background: The incidence rate of anemia in Indonesia shows a high value. Anemia is a decrease in the quantity or quality of red blood cells in the circulation. Anemia that often occurs in pregnancy is iron deficiency anemia. Deficiency of nutritional status could be the predispotitional factor of anemia in pregnancy in Indonesia. One of the indicator of nutritional status is the measurement of Middle Upper Arm Circumference MUAC) level. This research was aimed to determine the the relationship between Fe adequacy, dietary pattern and Middle Upper Arm Circumference (MUAC) level with anemia in pregnancy at Puskesmas Simpang Kawat Jambi city.

Methods: This research was a descriptive research with crosssectional design. A total of 97 respondents were recruited from a population of 526 using quota sampling. The respondent was pregnant women who visited the maternal and child health room of Puskesmas Simpang Kawat Jambi City.

Results: The results showed that 72 respondents had anemia (74,2\%). There was a correlation of Fe tablet consumption with anemia in pregnant women $(p=0,006)$. But no association were found between dietary pattern $(p=0,279)$ and middle upper arm circumference level $(p=0,178)$ with anemia in pregnant women. Conclusion: consumption of Fe tablet was associated with anemia in pregnant women, but no association were found between dietary pattern and middle upper arm circumference level with anemia in pregnant women.

Keyword: anemia in pregnancy; Fe tablet; middle upper arm circumference (MUAC) 


\section{PENDAHULUAN}

Angka Kematian Ibu (AKI) dan Angka Kematian Bayi (AKB) merupakan salah satu indikator yang menunjukkan status kesehatan. AKI di Indonesia berdasarkan SDKI 2012 mencapai 359/100.000 kelahiran hidup. Menurut WHO 40\% kematian ibu di negara berkembang berkaitan dengan anemia dalam kehamilan, sedangkan frekuensi ibu hamil dengan anemia di Indonesia relatif tinggi yaitu $63,5 \%{ }^{1}$

Menurut WHO (World Health Organization) kejadian anemia pada ibu hamil berkisar antara $20 \%$ sampai $89 \%$ dengan menetapkan $\mathrm{Hb} 11$ gr\% sebagai dasarnya. Angka kejadian anemia di Indonesia menunjukkan nilai yang cukup tinggi. WHO menemukan angka anemia pada tahun 1998 kehamilan 3,8\% pada trimester I, 13,6\% pada trimester II, dan $24,8 \%$ pada trimester III. Pada pengamatan lebih lanjut menunjukkan bahwa kebanyakan anemia yang diderita masyarakat adalah karena kekurangan zat Fe yang dapat diatasi melalui pemberian zat Fe secara teratur dan peningkatan gizi. ${ }^{2}$

Anemia adalah penurunan kuantitas atau kualitas sel-sel darah merah dalam sirkulasi. Anemia dalam kehamilan ialah kondisi ibu dengan kadar hemoglobin di bawah 11 gr\% pada trimester I dan III atau kurang dari 10.5 gr\% pada trimester II. Anemia yang sering terjadi pada kehamilan yaitu anemia defisiensi zat Fe, jenis anemia yang pengobatannya relatif mudah, bahkan murah. $^{2}$

Wanita hamil merupakan salah satu kelompok golongan yang rentan masalah gizi terutama anemia akibat kekurangan zat besi $(\mathrm{Fe})$. Kurangnya asupan besi (Fe) yang adekuat mengakibatkan timbulnya penyakit anemia gizi. Gejala tampak melalui kadar $\mathrm{Hb}$ dibawah 11 gr\%, pucat, lesu, letih, lemah dan terjadi perdarahan. ${ }^{1}$

Zat besi pada ibu hamil dibutuhkan untuk meningkatkan sintesis. Hemoglobin sebagai proses adaptasi terhadap adanya perubahan fisiologis pada ibu hamil yaitu terjadinya hemodilusi (pengenceran darah) dengan peningkatan volume $30 \%$ sampai $40 \%$ yang puncaknya pada kehamilan 32 sampai 34 minggu. Bila hemoglobin ibu sebelum hamil sekitar 11 gr\% maka dengan terjadinya hemodilusi akan mengakibatkan anemia fisiologis, dan $\mathrm{Hb}$ ibu akan menjadi 9,5 sampai 10 gr\%. Kebutuhan zat Fe pada ibu hamil sangat tergantung pada usia kehamilan yaitu pada trimester I kehamilan, kebutuhan zat Fe yang dibutuhkan sedikit karena pertumbuhan janin masih lambat. Memasuki trimester II hingga ke III, volume darah pada tubuh wanita meningkat.
Sedangkan saat melahirkan, wanita hamil butuh mengenal tablet Fe selama zat Fe sekitar $40 \mathrm{mg}$ per hari atau dua kali lipat dari kebutuhan wanita yang tidak hamil. ${ }^{2}$

Upaya penanggulangan anemia dilakukan melalui peningkatan cakupan suplementasi tablet Fe pada ibu hamil, Tablet Fe dikonsumsi mulai minggu ke 12 kehamilan yang di teruskan sampai 3 bulan pasca partum. Suplemen tablet Fe pada ibu hamil sampai nifas mendapatkan sebanyak 1 tablet dalam 1 hari berturut - turut selama minimal 90 hari masa kehamilannya, sampai 42 hari setelah melahirkan. ${ }^{1}$

Ketidakteraturan mengkonsumsi tablet Fe akan berakibat terjadi anemia, yang akan menimbulkan masalah seperti: pada ibu menjadi penyulit persalinan, risiko syok waktu persalinan, mudah terjadi penyakit selama kehamilan, keguguran, lahir prematur, bayi lahir dengan berat badan rendah, kelainan bawaan atau cacat bawaan, kematangan fungsi organ tubuh janin tidak sempurna. ${ }^{3}$

Keadaan yang sering terjadi adalah ibu hamil tidak teratur dalam meminum tablet $\mathrm{Fe}$, dikarenakan berbagai alasan yaitu faktor bosan, rasa obat yang tidak enak, membuat mual, takut anak yang dilahirkan akan besar, dan alasan lain yaitu lupa, dan tidak ada orang lain yang mengingatkan untuk meminumnya, sehingga konsumsi tablet basi tidak dipenuhi dengan baik. Dari keadaan tersebut bahwa sebenarnya pemerintah, masyarakat atau keluarga bisa berupaya membantu ibu hamil memperbaiki keadaan, khususnya dalam keteraturan mengkonsumsi tablet Fe secara teratur serta mengubah perilaku kesehatan mereka. Selain itu petugas kesehatan juga memegang peranan penting dalam memberikan informasi mengenai manfaat tablet $\mathrm{Fe}^{3}$

Frekuensi anemia dalam kehamilan diseluruh dunia cukup tinggi, berkisar antara $10 \%$ dan $20 \%$. Karena defisiensi makanan memegang peranan yang cukup penting dalam timbulnya anemia maka dapat dipahami bahwa frekuensi itu lebih tinggi lagi di negara-negara berkembang dibandingkan dengan negaranegara yang sudah maju. Frekuensi ibu hamil dengan anemia di Indonesia relatif tinggi yaitu $63,5 \%$. Kekurangan gizi dan perhatian yang kurang terhadap ibu hamil merupakan predisposisi anemia defisiensi ibu hamil di Indonesia. $^{2}$

Risiko anemia gizi pada ibu-ibu hamil lebih tinggi dibandingkan dengan wanita tidak hamil. Salah satu penyebabnya adalah pada ibu hamil diperlukan kebutuhan zat gizi yang meningkat. Selain untuk menutupi kehilangan basal (kehilangan zat besi melalui keringat, 
urine, dan kulit), juga dibutuhkan untuk keperluan pembentukan sel-sel darah yang bertambah banyak serta kebutuhan plasenta dan janin dalam kandungan. Di negara-negara sedang berkembang termasuk Indonesia banyak wanita yang memasuki masa kehamilan dengan cadangan zat besi dalam tubuhnya hanya sedikit dan sebagian lagi menderita kurang anemia zat besi. Wanita-wanita tersebut pada kehamilannya akan mempunyai kadar hemoglobin kurang dari normal $(<11 \mathrm{gr} / \mathrm{dl})$ untuk keadaan ini, WHO menganjurkan untuk memberikan suplementasi kepada ibu hamil, karena keperluan zat besi pada masa hamil tidak hanya dapat dipenuhi hanya dari makanan saja. Ibu hamil hanya disarankan untuk minum pil besi salama tiga bulan yang harus diminum setiap hari. Pil ini dibagikan secara gratis melalui kegiatan posyandu. Selain itu upaya yang bisa dilakukan untuk mengatasi anemia antara lain dengan memperbaiki menu makan. Dengan mengkonsumsi daging, ikan dan ayam serta makanan yang banyak mengandung vitamin $C$ untuk membantu penyerapan besi. ${ }^{1}$

Walaupun terdapat sumber makanan nabati yang kaya besi seperti daun singkong, kangkung dan sayuran berwarna hijau lainnya, namun zat Fe dalam makanan tersebut lebih sulit penyerapannya. Dibutuhkan porsi yang besar dari sumber nabati tersebut untuk mencukupi kebutuhan zat sehingga dalam kondisi kebutuhan Fe tidak terpenuhi dari makanan, maka pilihan untuk memberikan tablet besi folat dan sirup besi guna mencegah dan menanggulangi anemia menjadi sangat efektif dan efisien. Selain itu didaerah pedesaan banyak dijumpai ibu hamil dengan malnutrisi atau kekurangan gizi, kehamilan dan persalinan dengan jarak yang berdekatan, dan ibu hamil dengan pendidikan dan tingkat sosial ekonomi rendah. ${ }^{2}$

Anemia defisiensi besi pada wanita hamil merupakan problema kesehatan yang dialami oleh wanita seluruh dunia termasuk di negara berkembang. Badan kesehatan dunia, WHO, melaporkan bahwa prevalensi ibu-ibu hamil yang mengalami defisiensi Fe sekitar 20\% sampai $89 \%$ serta semakin meningkat seiring dengan bertambahnya usia kehamilan. ${ }^{2}$

Anemia defisiensi besi pada wanita hamil mempunyai dampak buruk baik pada ibunya maupun terhadap janinnya. Ibu hamil dengan anemia berat lebih memungkinkan terjadinya partus prematur dan memiliki bayi dengan berat badan lahir rendah serta dapat meningkatkan kematian perinatal. Menurut WHO 40\% kematian ibu di negara berkembang dikaitkan dengan anemia pada kehamilan dan kebanyakan anemia pada kehamilan disebabkan oleh defisiensi besi dan perdarahan akut. Bahkan tidak jarang keduanya saling berinteraksi. ${ }^{2}$

Keteraturan ibu hamil dalam mengkonsumsi tablet $\mathrm{Fe}$ dalam hal ini sangat berpengaruh karena efek samping tablet Fe yang mengganggu sehingga orang cenderung menolak tablet Fe yang diberikan, efek samping tersebut dapat berupa pengaruh yang tidak menyenangkan seperti rasa tidak enak di ulu hati, mual, muntah dan diare (terkadang juga konstipasi) penyulit ini tidak jarang menyusutkan ketaatan pasien selama pengobatan berlangsung. Penolakan tersebut sebenarnya berpangkal dari ketidaktahuan mereka bahwa selama kehamilan mereka memerlukan tambahan zat besi, jika situasi ini berkembang, dosis sebaiknya diturunkan sampai pengaruh itu lenyap. Sementara itu, ibu hendaknya diberi pengertian bahwa pengaruh yang tidak menyenangkan tidak ada artinya jika dibandingkan dengan besarnya manfaat zat besi dan harus pula diyakinkan bahwa salah satu penyebab anemia pada ibu hamil adalah defisiensi zat besi, suplemen zat besi atau pemberian tablet Fe merupakan salah satu upaya penting dalam mencegah dan menanggulangi anemia. ${ }^{4}$

Pengukuran lingkar lengan atas (LILA) diperlukan dalam pelaksanaan program KIE gizi bagi ibu hamil. Ukuran lila normal adalah di atas $23,5 \mathrm{~cm}$, ibu dengan ukuran lila dibawah $23,5 \mathrm{~cm}$ menunjukkan adanya kekurangan energi kronis. ${ }^{5}$

Berdasarkan data yang didapat dari dinas kesehatan kota Jambi bahwa kejadian anemia di kota Jambi bervariasi dari puskesmas ke puskesmas lainnya. Dari 20 puskesmas yang ada di Kota Jambi kejadian anemia paling banyak adalah puskesmas Simpang Kawat yaitu dari 526 ibu hamil yang diperiksa kadar $\mathrm{Hb}$ nya, terdapat $193(36,7 \%)$ ibu hamil yang mempunyai kadar $\mathrm{Hb}<11$ gr \% atau anemia. Data pengukuran LILA dari $526 \mathrm{ibu}$ hamil yang diukur LILA, terdapat 25 orang (\%) ibu yang LILA $<23,5 \mathrm{~cm}^{6}$

Pada survey awal yang dilakukan pada 2 orang ibu hamil, diketahui satu orang ibu mengatakan tidak teratur mengkonsumsi tablet fe karena lupa, sedangkan 1 orang ibu hamil mengatakan sudah teratur mengkonsumsi tablet fe nya hanya saja ukuran lingkar lengannya masih dibawah $23,5 \mathrm{~cm}$. Ibu hamil yang mengkonsumsi tablet $\mathrm{Fe}$ secara teratur masih mengalami anemia apalagi pada ibu hamil yang tidak mengkonsumsi tablet Fe secara teratur. Berdasarkan data dan survey awal penulis akan melakukan penelitian tentang hubungan kecukupan konsumsi Tablet Fe, pola makan dan ukuran lingkar lengan atas (LILA) dengan 
anemia ibu hamil di Puskesmas Simpang Kawat Kota Jambi Tahun 2017.

\section{METODE}

Penelitian ini menggunakan rancangan cross sectional, bertujuan untuk mengetahui hubungan kecukupan konsumsi tablet Fe, pola makan dan ukuran LILA dengan anemia pada ibu hamil di Puskesmas Simpang Kawat, yang dilaksanakan pada bulan Mei s/d Agustus 2017. Populasi dalam penelitian ini sebanyak 526 ibu hamil, sampel sebanyak 97 orang ibu hamil, diambil secara quota sampling. Data untuk variabel anemia diperoleh melalui pemeriksaan kadar hemoglobin dan pengukuran lingkar lengan atas (LILA) responden, sedangkan untuk variabel kecukupan konsumsi tablet Fe dan pola makan diukur melalui pengisian kuesioner. Instrumen penelitian untuk variabel pola makan menggunakan Food Frequency (FFQ).

\section{HASIL DAN PEMBAHASAN}

Berdasarkan hasil penelitian yang ditampilkan pada tabel 1, distribusi responden berdasarkan karakteristik responden diketahui bahwa sebagian responden berada dalam rentang usia 20-35 tahun sebanyak 85 orang $(87,6 \%)$, mayoritas memiliki pendidikan $\geq$ SMA sebanyak 78 orang $(80,4 \%)$, pekerjaan terbanyak yaitu ibu rumah tangga sebanyak 76 orang $(78,4 \%)$, sedangkan berdasarkan gravida terbanyak adalah kehamilan 2-3 yaitu 55 orang $(56,7 \%)$.

Tabel 1. Distribusi Karakteristik Responden di PKM Simpang Kawat Tahun 2017

\begin{tabular}{|c|c|c|c|}
\hline \multicolumn{2}{|c|}{ No Karakteristik } & \multicolumn{2}{|c|}{ Jumlah } \\
\hline & & f & $\%$ \\
\hline & Usia & 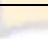 & \\
\hline & $<20$ Tahun & 1 & 1,1 \\
\hline & 20-35 Tahun & 85 & 87,6 \\
\hline & $>35$ Tahun & 11 & 11,3 \\
\hline \multirow[t]{3}{*}{2} & Pendidikan & & \\
\hline & $<$ SMA & 19 & 19,6 \\
\hline & $\geq \mathrm{SMA}$ & 78 & 80,4 \\
\hline \multirow[t]{5}{*}{3} & Pekerjaan & & \\
\hline & PNS & 9 & 9,3 \\
\hline & SWASTA & 9 & 9,3 \\
\hline & BURUH/DAGANG & 3 & 3,0 \\
\hline & IRT & 76 & 78,4 \\
\hline \multirow[t]{4}{*}{$\overline{4}$} & Gravida & & \\
\hline & 1 & 29 & 29,9 \\
\hline & $2-3$ & 55 & 56,7 \\
\hline & $>3$ & 13 & 13,4 \\
\hline
\end{tabular}

Berdasarkan hasil penelitian yang ditampilkan pada tabel 2, diketahui distribusi anemia ibu hamil di Puskesmas Simpang Kawat Kota Jambi sebagian besar responden mengalami anemia yaitu sebanyak 72 orang $(74,2 \%)$. Berdasarkan kecukupan Konsumsi Fe, pola makan dan ukuran LILA dapat diketahui bahwa sebagian responden cukup dalam mengkonsumsi tablet Fe yaitu sebanyak 53 responden $(54,64 \%)$, dan sebagian besar memiliki pola makan yang baik sebanyak 86 responden $(88,66 \%)$ dan sebagian responden memiliki ukuran lingkar lengan atas (LILA) $\geq 23,5 \mathrm{~cm}$ sebanyak 85 org $(87,63 \%)$.

Tabel 2. Hubungan Kecukupan Konsumsi Fe, Pola Makan dan Ukuran LILA dengan Anemia Ibu Hamil di PKM Simpang Kawat Kota Jambi Tahun 2017

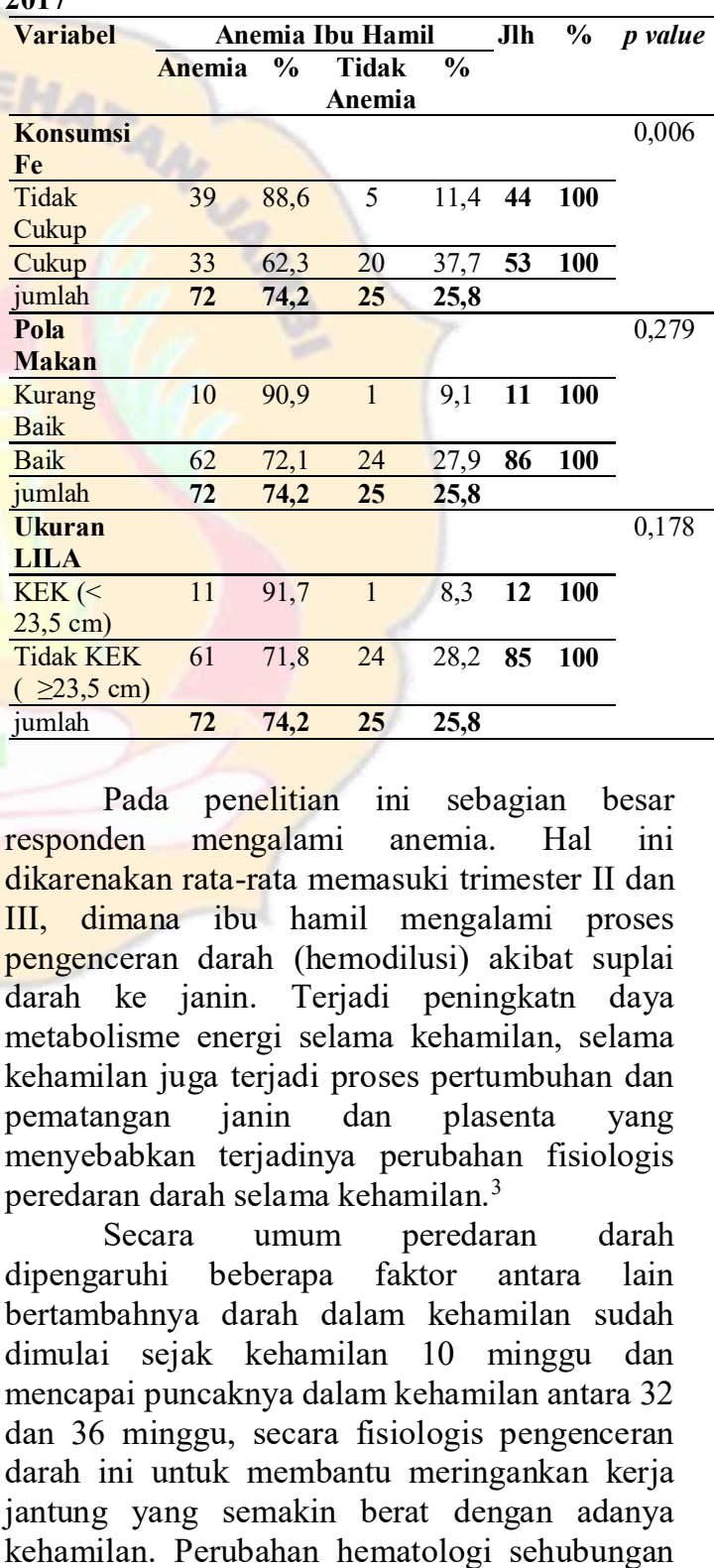


dengan kehamilan karena perubahan sirkulasi yang makin meningkat terhadap plasenta dan pertumbuhan payudara. Volume plasma meningkat $45 \%$ dimulai trimester II kehamilan dan maksimum terjadi pada bulan ke-9 dan meningkatnya sekitar $1000 \mathrm{ml}$, menurun sedikit menjelang aterm serta kembali normal 3 bulan setelah melahirkan. ${ }^{7}$

Hemoglobin merupakan indikator yang digunakan untuk mengetahui kekurangan besi. Nilai hemoglobin berguna untuk mengetahui beratnya anemia dan nilai hemoglobin rendah menggambarkan kekurangan besi. ${ }^{8}$ Metode yang digunakan dalam pengukuran Hemoglobin antara lain metode sahli dan metode cyanmethemoglobin. ${ }^{9}$

Anemia sering terjadi akibat defisiensi zat besi karena pada ibu hamil terjadi peningkatan kebutuhan zat besi dua kali lipat akibat peningkatan volume darah tanpa ekspansi volume plasma, untuk memenuhi kebutuhan ibu (mencegah kehilangan darah pada saat melahirkan) dan pertumbuhan janin. ${ }^{2}$

Konsumsi tablet tambah darah ibu hamil sudah mencukupi apabila ibu hamil telah mengkonsumsi sebanyak 90 tablet TTD yang mengandung $60 \mathrm{mg}$ elemental iron dan 0,25\% asam folat yang diminum satu tablet sehari. ${ }^{1}$

Distribusi hubungan kecukupan konsumsi fe dengan anemia ibu hamil di Puskesmas Simpang kawat Kota Jambi pada tabel 2 menunjukkan bahwa dari 44 responden yang tidak cukup mengkonsumsi tablet $\mathrm{Fe}$, yang mengalami anemia sebanyak 39 orang $(88,66 \%)$, dari 53 responden yang cukup mengkonsumsi tablet $\mathrm{Fe}$, yang mengalami anemia sebanyak 33 orang $(62,3 \%)$. Berdasarkan uji statistik diketahui ada hubungan kecukupan konsumsi Fe dengan anemia ibu hamil dengan $p$ value sebesar $0,006(<\alpha 0,05)$.

Kecukupan konsumsi tablet $\mathrm{Fe}$ mempunyai hubungan dengan kejadian anemia ibu hamil, karena anemia defisiensi besi merupakan masalah yang paling banyak terjadi. Defisiensi besi adalah berkurangnya jumlah besi yang ada dalam tubuh. Pada tingkat awal cadangan besi di retikulo endotelial menurun akibatnya kadar feritin plasma menurun dan berdampak pada peningkatan absorpsi zat besi. Kadar hb dan besi serum menurun tetapi belum terjadi perubahan biokimia dan belum memperlihatkan gejala klinis. Pada tingkat laten cadangan besi di retikulo endotelial menurun dan serum feritin juga mengalami penurunan terjadi perubahan biokimia tubuh yaitu besi serum menurun dan terjadi peningkatan free eriyhtrocyte protophorphyrin (FEP) tetapi kadar $\mathrm{Hb}$ masih normal. Pada tingkat anemia defisiensi besi merupakan tingkatan terakhir dari defisiensi besi. Cadangan besi sangat menurun bahkan bisa tidak ada sama sekali. Terjadi perubahan biokimia tubuh seperti besi serum sangat menurun, kadar hb menurun dan terjadi pengingkatan jumlah FEP, sudah kelihatan gejala klinis dan terjadi perubahan pada epitel. Pada tingkat ini sudah terjadi anemia. ${ }^{8}$

Anemia besi adalah anemia yang disebabkan kekurangan zat besi, hal ini disebabkan oleh kekurangan konsumsi zat besi dan dapat juga disebabkan rendahnya tingkat absorpsi zat besi akibat dari rendahnya konsumsi zat yang dapat membantu absoprsi zat besi serta tngginya konsumsi zat yang menghambat absorsi zat besi. ${ }^{1}$

Penelitian Indahswari menunjukkan ada hubungan signifikan antara frekuensi konsumsi zat besi non heme dengan kejadian anemia pada wanita prakonsepsi di kecamatan ujung tanah dan kecamatan biringkanaya kota Makassar, namun tidak terdapat hubungan frekuensi konsumsi makanan yang mengandung zat besi heme, frekuensi makanan yang mengandung pelancar absorpsi zat besi, makanan penghambat absorpsi dengan kejadian anemia ibu hamil. ${ }^{11}$

Kecenderungan ibu hamil yang mengkonsumsi tablet Fe baik ( $\geq 90$ tablet) memiliki risiko kejadian anemia lebih rendah dibandingkan ibu yang mengkonsumsi tablet $\mathrm{Fe}$ $<90$ tablet di wilayah kerja Puskesmas Tawang sari Sukoharjo dengan $(\alpha 0,044) .{ }^{13}$

Penelitian Alizadeh et.al menunjukkkan ada perbedaan signifikan pada 2 kelompok yang diberikan tablet $\mathrm{Fe}$ dan plasebo mulai dari kehamilan 20 minggu sampai trimester akhir, menujukkan perbedaan kadar Hemoglobin $(p=0 / 03)$ dan ferritin $(p=0 / 04) .^{14}$

Hal ini diperkuat dengan penelitian Taye dari 628 responden yang diberikan suplementasi tablet besi, menunjukkan ada hubungan umur, pendidikan dan pengetahuan tentang konsumsi Fe serta riwayat anemia dengan pemberian suplementasi Fe ibu hamil. ${ }^{15}$

Adapun hubungan pola makan dengan anemia ibu hamil di PKM Simpang Kawat Kota Jambi ditemukan bahwa dari 11 responden yang memiliki pola makan kurang baik, terdapat 10 responden yang mengalami anemia $(90,9 \%)$, dan dari 86 rsponden yang memiliki pola makan yang baik yang mengalami anemia sebanayak 62 orang $(72,1 \%)$. Berdasarkan uji statistik diketahui tidak ada hubungan pola makan dengan anemia ibu hamil di PKM Simpang Kawat Kota Jambi Tahun 2017 dengan $p$ value sebesar 0,279 $(>\alpha 0,05)$.

Pola makan yang salah membawa dampak terhadap terjadinya gangguan gizi antara 
lain anemia, pertambahan berat badan yang kurang pada ibu hamil dan gangguan pertumbuhan janin. Penyebab langsung terjadinya anemia antara lain defisiensi asupan gizi dari makanan (zat besi, asam folat, protein, vitamin $\mathrm{C}$, riboflavin, vitamin $\mathrm{A}$, seng dan Vitamin B12), konsumsi zat-zat penghambat penyerapan besi, penyakit infeksi, malabsorpsi, perdarahan dan peningkatan kebutuhan selama kehamilan. ${ }^{10}$

Hasil penelitian ini berbeda dengan yang ditemukan pada penelitian sebelumnya di Puskesmas Dawe Kabupaten Kudus yang menunjukkan ada hubungan pola makan (kuantitas makanan, jenis makanan dan cara memasak makanan) dengan terjadinya anemia pada ibu hamil. ${ }^{13}$

Hubungan pola makan dengan kejadian anemia ibu hamil Trimester III juga ditemukan di di Puskemas Pleret bantul. ${ }^{16}$ Ditemukan pula hubungan frekuensi makan dan jenis makanan dengan kejadian anemia di wilayah kerja Puskesmas Kerjo Kabupaten Karanganyar. ${ }^{10}$

Hubungan ukuran LILA dengan anemia ibu Hamil di PKM Simpang Kawat Kota Jambi Tahun 2017 diketahui dari 12 responden yang memiliki ukuran LILA KEK, yang mengalami anemia sebanyak 11 orang $(91,7 \%)$, dan dari 85 responden dengan ukuran LILA $\geq 23,5 \mathrm{~cm}$ yang mengalami anemia sebanyak 61 orang $(71,8 \%)$. Berdasarkan uji statistik diketahui tidak ada hubungan ukuran lingkar lengan atas (LILA) dengan anemia ibu hamil di Puskesmas Simpang Kawat Kota Jambi dengan $p$ value sebesar 0,178 $(>\alpha 0,05)$.

Hasil penelitian ini berbeda dengan penelitian Saaka et. al pada 400 ibu hamil yang menunjukkan bahwa walaupun tidak terdapat hubungan pola makan wanita hamil pada daerah pedesaan di Ghana dengan anemia, akan tetapi ada hubungan ukuran lingkar lengan atas (Mid Upper Arm Circumference), usia kehamilan dan frekuensi ANC dengan anemia ibu hamil. ${ }^{17}$

Penelitian lainnya yang dilakukan di Ethiopia, menunjukkan bahwa status trimester, gravida, pemberian suplemen besi dan ukuran LILA berhubungan secara signifikan dengan kejadian anemia pada ibu hamil. ${ }^{18}$ BMI dan LILA juga ditemukan berhubungan signifikan dengan anemia pada mahasiswa wanita di Pakistan. ${ }^{19}$

Anemia pada ibu hamil dapat terjadi dengan penyebab yang multifaktorial. Meningkatnya volume darah saat kehamilan menyebabkan meningkat pula kebutuhan zat besi tubuh. Usia ibu hamil maupun usia kehamilan, status gravida, asupan zat besi, kondisi hormonal dan pola makan juga mempengaruhi kondisi anemia pada ibu hamil. Oleh karena itu tidak dapat ditentukan secara tunggal penyebab anemia yang terjadi pada masing masing ibu hamil. ${ }^{20}$

\section{KESIMPULAN}

Berdasarkan hasil penelitian di Puskesmas Simpang Kawat Kota Jambi tahun 2017, dapat disimpulkan bahwa sebagian besar $(74,2 \%)$ ibu hamil mengalami anemia. Terdapat hubungan antara konsumsi Fe dengan anemia pada ibu hamil. Pola makan dan ukuran LILA tidak berhubungan dengan kejadian anemia pada ibu hamil.

Diharapkan hasil penelitian ini sebagai masukan untuk menyusun kebijakan dalam peningkatan pelayanan pada ibu hamil, khususnya pemantauan kecukupan konsumsi tablet Fe dalam menurunkan kasus anemia pada ibu hamil di Kota Jambi. Disarankan kepada pihak Puskesmas khususnya petugas kesehatan untuk memantau kecukupan konsumsi tablet Fe dan menangani kejadian anemia pada ibu hamil di wilayah kerja Puskesmas.

\section{DAFTAR PUSTAKA}

1. Kemenkes RI. Pedoman Penatalaksanaan Pemberian Tablet Tambah Darah. Jakarta: Kementrian Kesehatan RI. 2015.

2. Manuaba IB. Gawat darurat obstetri ginekologi dan obstetri ginekologi sosial untuk profesi bidan. Jakarta: EGC. 2008:296-99.

3. Tarwoto dan Wasnidar. Buku saku anemia pada ibu hamil dan konsep penatalaksanaan. Jakarta : Trans Info Media. 2007.

4. Arisman MB. Buku Ajar Ilmu Gizi Dalam Daur Kehidupan. Edisi-2. Jakarta: EGC. 2010.

5. Sulistyoningsih, H. Gizi untuk Kesehatan ibu dan anak, Jogyakarta: Graha Ilmu. 2011.

6. Dinas Kesehatan Kota Jambi. Laporan Hasil Kegiatan Program Ibu dan Anak di Kota Jambi, Dinkes Kota. Jambi. 2016.

7. Prawirohardjo. Ilmu Kebidanan, YBPSP Jakarta. 2010.

8. Almatsier. Prinsip Dasar Ilmu Gizi, PT Gramedia Pustaka Utama Jakarta. 2005.

9. Supariasa,I.D.N dkk, 2012,Penilaian Status Gizi, EGC, Jakarta

10. Pertiwi, A, 2013, Hubungan antara Pol Makan dengan Kejadian Anemia pada Ibu Hamil di Wilayah Kerja Puskesmas Kerjo karang Anyar, Skripsi Universitas Uhammmadyah Surakarta.

11. Indahswari, L, Thaha,A Razak, Syam, A (2013) Hubungan Pola Konsumsi dengan kejadian anemia pada wanita prakkonsepsi di kecamatan Ujung Tanah dan kecamatan Biringkanaya Kota 
Makasar, Jurnal Media kesehatan Masyarakat Indonesia tahun 2013.

12. Nurhidayati. Analisis faktor penyebab terjadinya anemia pada ibu hamil di Wilayah Kerja Puskesmas Tawangsari Kabupaten Sukoharjo. Skripsi Universitas Muhammadyah Surakarta. 2013.

13. Suranto S, Karyati S, Sholihah S. Hubungan Antara Pola Makan dengan Terjadinya Anemia Pada Ibu Hamil di Puskesmas Dawe Kecamatan Dawe Kabupaten Kudus Tahun 2013. Jurnal Ilmu Keperawatan dan Kebidanan. 2013 Jan 19;4(1).

14. Alizadeh L, Salehi L. Is routine Iron supplementation necessary in pregnant women with high hemoglobin?. Iranian Red Crescent Medical Journal. 2016 Jan;18(1).

15. Taye B, Abeje G, Mekonen A. Factors associated with compliance of prenatal iron folate supplementation among women in Mecha district, Western Amhara: a cross-sectional study. Pan African Medical Journal. 2015;20(1).

16. Zulaikha. Hubungan pola makan dengan kejadian anemia pada ibu hamil trimester III di Puskesmas Pleret Bantul Tahun 2015. Skripsi Stikes Aisyiyah Yogyakarta. 2015.

17. Saaka M, Oladele J, Larbi A, Hoeschle-Zeledon I. Dietary diversity is not associated with haematological status of pregnant women resident in rural areas of northern Ghana. Journal of nutrition and metabolism. 2017.

18. Addis Alene K, Mohamed Dohe A. Prevalence of anemia and associated factors among pregnant women in an urban area of Eastern Ethiopia. Anemia. 2014;2014.

19. Laghari ZA, Baig NM, Memon F, Panhwar F, Qambarani MR, Palh ZA. Correlation of BMI and MUAC with anemia among Sindh University Students, Jamshoro, Pakistan. Sindh University Research Journal-SURJ (Science Series). 2017 Nov 20;49(3):553-6.

20. Campigotto AC, Pinto DC, Albuquerque FG. Factors relating to iron deficiency anemia in pregnancy: an integrative review. International Archives of Medicine. 2015; 8(159): 1-11 